\title{
PRESCHOOL TEACHERS' TRAINING AND ATTITUDES TOWARDS MULTICULTURAL EDUCATION IN MALAYSIA
}

\author{
Melissa Ng Lee Yen Abdullah ${ }^{1}$, Anna Christina Abdullah ${ }^{2}$ \\ School of Educational Studies, Universiti Sains Malaysia (USM), Penang, Malaysia ${ }^{1}$, \\ School of Education, Languages and Communications, Wawasan Open University, \\ Penang, Malaysia ${ }^{2}$ \\ melissa@usm.my ${ }^{1}$, annachristinaa@wou.edu.my²
}

\begin{abstract}
Multicultural education is crucial in promoting cross-cultural understanding, recognition, and celebration of diversity in Malaysia-one of the most culturally diverse countries in the world. Preschool teachers play central roles in laying the foundation for cultural acceptance and positive racial interaction during early childhood. This study aims to explore Malaysian preschool teachers' training and attitudes towards multicultural education. A quantitative questionnaire survey approach was used to gather the required data. The participants consisted of 1,067 preschool teachers from 267 private and government preschools providers in the country. Two validated instruments were employed to measure the variables in this study. The trainings received by the preschool teachers were measured by the Teachers' Training Multicultural Education Scale (TTMES) while their attitudes towards multicultural education were gauged by the Multicultural Teaching Scale (MTS). Findings showed that preschool teachers were positive about the trainings that they received in relation to multicultural education. However, the extent to which they actually understood the concept of multiculturalism was doubtful in view that two thirds of the teachers demonstrated misconception about the fundamental principles of multicultural education when their attitudes towards multicultural education were examined. Significant differences were found in teachers' training and attitudes according to the categories of preschools; teachers from mono-cultural preschools displayed the least positive attitudes towards multicultural education. Implications of the study were discussed in the paper.
\end{abstract}

Keywords: multicultural education, early childhood, preschool teachers, teacher education, attitudes

\section{INTRODUCTION}

Initiatives to promote cultural awareness, co-existence and cooperation among the different racial and ethnic groups in Malaysia has begun since the country gained independence 50years ago (Abdullah, 2009). Malaysia is one of the most plural and heterogeneous countries in the world. The diversity is reflected in the variety of languages spoken and religious backgrounds, even within the same ethnic group various traditions prevail. In the past decades, many national programmes and initiatives targeting at inter-ethnic integration have been implemented, yet a pattern of increasing polarization among the population seems to be on the upward trend. In an attempt to reverse this trend, the Malaysian government has made it compulsory for all university undergraduates to take a stand-alone course on ethnic relations which aimed to encourage interactions between adolescents from different ethnic groups at the tertiary level. However, such effort could not produce the desirable outcome as it might be the case of "too little, too late". It is extremely difficult to undo any pre-existing prejudices, negative attitudes and biases that have been internalised by young adults at the university (Abdullah, 2009). Hence, the prime time for multicultural education is during childhood (Denham, et al., 2012). Multicultural education should be introduced during 
preschool years to help young children develop moral values and ethical standards of their society as early as possible (Phoon, Abdullah \& Abdullah, 2012). Embracing cultural diversity during young age may avoid or minimize the later development of cultural prejudices, stereotypes and biases. Multicultural early childhood education can promote cross-cultural understanding, recognition, and celebration of diversity (Brahim \& Syarif, 2010; Ogletree \& Patricia, 2010), particularly in a multi-cultural and multi-religious country like Malaysia. Preschool teachers play a crucial role in planting the seeds for cultural acceptance and positive racial interaction among young children (Curriculum Development Centre, 2008). Effective teacher training on multiculturalism will ensure all preschool teachers have positive mind set, strong conceptual understanding of multicultural education and adequate pedagogical skills to carry out instructional practices that are grounded in the principles of democracy, equity and justice.

\section{Professional training}

In Malaysia, teacher training programs are offered by various higher education institutions, including Universiti Malaya, Universiti Kebangsaan Malaysia, Sultan Idris Teaching Universiti and the Open University of Malaysia. At the foundation level, certificate program is also available for in-service preschool teachers, administrators as well as parents and other parties who are interested to know more about early childhood education. In addition, universities also offer post-graduate diploma and a four-year integrated bachelor degree course on early childhood education. To cater for the increasing demand for trained preschool teachers, Teacher Training Colleges also play critical roles in offering diploma program and post graduate diploma to develop the much needed human resource in the area.

There are also a number of private colleges (e.g., SEGI College and Kirkby International College) that offer a variety of teacher training courses (Curriculum Development Center, 2008). However, due to scarcity of research, it is unclear to what extent preschool teachers in Malaysia are equipped with knowledge and skills on multicultural education. Literature reviews show that it is important for teachers to undergo professional trainings to practice multiculturalism. Teacher education should cover key elements on diversity, which include sense of identities, understanding and skills to deals with prejudicism and racism, knowledge on various ethno-cultural groups including their learning styles as well as instructional practices and strategies in a culturally diverse educational setting. Through professional training, teachers will develop a clearer sense of own ethic and cultural identities. This knowledge is critical for them to self-reflect and avoid any predetermined biases when planning and conducting lessons. The training programs should also address the nature and causes of racism and equip teachers with research-based instructional approaches to deal with it. In addition, the histories, cultural values and contribution of various ethnocultural groups ought to be touched in the curriculum. Teachers should also be exposed to information regarding the characteristics and learning styles of the different groups to help them identify the instructional approach that appeals to diverse learners. In order to be effective teachers, the training programs must demonstrate successful teaching of ethnic and language minority students and how instructions can be embedded in a group setting to provide both intellectual challenge and social support (Zeichner, 1993). 


\section{Teachers' attitudes towards multicultural education}

Teachers' attitudes towards multicultural early childhood education are crucial because "effective teachers would use knowledge of their students' culture and ethnicity as a framework for inquiry and they organise and implement instruction" (Banks et al., 2001:198). In order to implement multicultural and anti-bias curriculum effectively, teachers must examine their own attitudes such as beliefs and perspective towards various cultural groups. Research shows that teacher with positive attitudes tend to "use knowledge of their students' culture and ethnicity as a framework for inquiry and instruction" (Banks, 2001:198). Trainings on multicultural education is a crucial step to cultivate teachers' positive attitudes and values. According to Assaf, Garza and Battle (2010), many teacher candidates may come to teacher education programs with stereotypical beliefs and deficit attitudes about students with certain sociocultural backgrounds. Teacher training programs, however, can alter these attitudes and impact the teachers' practices and beliefs in multicultural classrooms in a positive manner. Teachers with training in multicultural education could engage in higher levels of combating prejudice at schools and are more likely to build positive relationships with multicultural students. They are more prepared in multicultural educational practices and are likely to change instructional strategies to work in a multicultural environment.

\section{Early childhood education providers in Malaysia}

In Malaysia, early childhood education is provided by both government and private preschools. The government run preschools fall under the purview of three government agencies; the Ministry of Rural and Regional Development, the Department of National Unity and Integration and the Ministry of Education (MOE) (Curriculum Development Center, 2008). In early 1970s, the Ministry of Rural and Regional Development set up the KEMAS (Jabatan Kemajuan Masyarakat) or the Community Development Department preschools. The KEMAS preschools were launched after the Malaysian New Economic Policy in 1970 to cater for the educational needs of young children in the rural or suburban areas. A total of 8,307 preschools have since been set up based on the request of the local authority (Curriculum Development Center, 2008). In the late 1970s, the Department of National Unity and Integration has taken the initiatives to set up the PERPADUAN or unity preschools in the urban areas. These preschools aim to embrace diversity and accept children from diverse cultural and ethnicity backgrounds. There are 1,496 PERPADUAN preschools in the country. In 2003, the Ministry of Education (MOE) has established the Annex preschools which operate within the compound of government primary schools. There are 5,905 MOE-Annex preschools situated all over the country. Apart from preschools under the various government agencies, there are also religious-based preschools under the State Islamic Religion Department (JAIN) and private commercial preschools (Curriculum Development Centre, 2008).

\section{Research Objectives}

Studies focusing on multicultural teacher education in Malaysia are scare (Abdullah, Mohd Yusof \& Ahmad, 2010; Abdullah et al., 2011) more so studies that look into teachers' training and attitudes towards multicultural education. A study by Phoon, Abdullah and 
Abdullah (2012) have explored preschool teachers' attitudes qualitatively, but there is no large scale research that measure and examine preschool teachers' training and attitudes empirically in a multicultural and heterogeneous country like Malaysia. It is, thus, unclear to what extent Malaysian preschools teachers are prepared for diversity and multicultural education. Even though most teachers at the government-run preschools received training in early childhood education, the coverage and focus on multicultural education component may not be sufficient. Studies show that majority of the primary and secondary school teachers have limited understanding about multicultural education and are not equipped with the skills to integrate and infuse culturally responsive pedagogy across the curricula (Sharifah \& Mohamed, 2011). There are critical needs to determine whether similar trends and issues also exist among the preschool teachers who are responsible to lay the foundation for multicultural education. The lack of empirical findings on preschool teachers' training and attitudes towards multicultural education calls for a study to fill in the literature gaps. The following research objectives were formulated to guide the investigation:

1. To describe preschool teachers' training and attitudes towards multicultural education.

2. To determine whether preschool teachers' training and attitudes towards multicultural education differs according to categories of preschools.

\section{METHOD}

\section{Participants}

A total of 1,067 preschool teachers from 267 private and government preschool in the northern region of Peninsular Malaysia have participated in this research. Table 1 shows the demographic profile of preschool teachers. Stratified sampling technique was used to select the samples from government (e.g., MOE-Annex, KEMAS, PERPADUAN preschools) and non-government run preschools (e.g., Religious-based and private commercial preschools).

Table 1: Demographic Profile of Preschool Teachers

\begin{tabular}{|c|c|c|c|c|c|c|c|c|c|c|c|c|}
\hline \multirow[t]{2}{*}{ Profile } & \multicolumn{2}{|c|}{$\begin{array}{c}\text { MOE (Annex) } \\
\quad(n=310)\end{array}$} & \multicolumn{2}{|c|}{$\begin{array}{c}\text { KEMAS } \\
(\mathrm{n}=388)\end{array}$} & \multicolumn{2}{|c|}{$\begin{array}{c}\text { PERPADUAN } \\
(\text { JPNIN }) \\
(\mathrm{n}=286)\end{array}$} & \multicolumn{2}{|c|}{$\begin{array}{c}\text { Religious } \\
(\text { JAIN) } \\
(\mathrm{n}=19) \\
\end{array}$} & \multicolumn{2}{|c|}{$\begin{array}{c}\text { Private } \\
\text { Commercial } \\
(n=20)\end{array}$} & \multicolumn{2}{|c|}{$\begin{array}{l}\text { Total } \\
(\mathrm{N}=1,067)\end{array}$} \\
\hline & $\mathrm{f}$ & $\%$ & $\mathrm{f}$ & $\%$ & $\mathrm{f}$ & $\%$ & $\mathrm{f}$ & $\%$ & $\mathrm{f}$ & $\%$ & $\mathrm{f}$ & $\%$ \\
\hline $\begin{array}{l}\text { Gender } \\
\text { Male } \\
\text { Female }\end{array}$ & $\begin{array}{c}26 \\
283\end{array}$ & $\begin{array}{c}8.4 \\
91.6\end{array}$ & $\begin{array}{c}4 \\
282\end{array}$ & $\begin{array}{c}1.0 \\
99.0\end{array}$ & $\begin{array}{c}5 \\
279\end{array}$ & $\begin{array}{c}1.8 \\
98.2\end{array}$ & $\begin{array}{c}1 \\
18\end{array}$ & $\begin{array}{c}5.3 \\
94.7\end{array}$ & $\begin{array}{c}3 \\
17\end{array}$ & $\begin{array}{l}15.0 \\
85.0\end{array}$ & $\begin{array}{l}37 \\
1,022\end{array}$ & $\begin{array}{l}3.4 \\
96.6\end{array}$ \\
\hline $\begin{array}{l}\text { Ethnicity } \\
\text { Malay } \\
\text { Chinese } \\
\text { India } \\
\text { Others }\end{array}$ & $\begin{array}{c}281 \\
21 \\
6 \\
1 \\
\end{array}$ & $\begin{array}{c}90.9 \\
6.8 \\
1.9 \\
0.3 \\
\end{array}$ & $\begin{array}{c}381 \\
- \\
- \\
-\end{array}$ & $\begin{array}{c}100 \\
- \\
- \\
-\end{array}$ & $\begin{array}{c}243 \\
8 \\
27 \\
4 \\
\end{array}$ & $\begin{array}{c}86.2 \\
2.8 \\
9.6 \\
1.4 \\
\end{array}$ & $\begin{array}{c}19 \\
- \\
- \\
-\end{array}$ & $\begin{array}{c}100 \\
- \\
- \\
-\end{array}$ & $\begin{array}{c}13 \\
5 \\
1 \\
-\end{array}$ & $\begin{array}{c}68.4 \\
26.3 \\
5.3 \\
-\end{array}$ & $\begin{array}{l}974 \\
32 \\
35 \\
5 \\
\end{array}$ & $\begin{array}{l}93.1 \\
3.3 \\
3.1 \\
0.5 \\
\end{array}$ \\
\hline $\begin{array}{l}\text { Age } \\
20 \leq \\
21-30 \\
31-40 \\
41-50 \\
51 \geq\end{array}$ & $\begin{array}{c}3 \\
65 \\
134 \\
103 \\
5\end{array}$ & $\begin{array}{c}1.0 \\
21.0 \\
43.2 \\
33.2 \\
1.6\end{array}$ & $\begin{array}{c}6 \\
94 \\
87 \\
126 \\
75\end{array}$ & $\begin{array}{c}1.5 \\
24.2 \\
22.4 \\
32.5 \\
19.3\end{array}$ & $\begin{array}{c}6 \\
47 \\
82 \\
121 \\
29\end{array}$ & $\begin{array}{c}2.1 \\
16.5 \\
28.8 \\
12.5 \\
10.2\end{array}$ & $\begin{array}{l}3 \\
1 \\
6 \\
7 \\
2\end{array}$ & $\begin{array}{c}15.8 \\
5.3 \\
31.6 \\
36.8 \\
10.5\end{array}$ & $\begin{array}{c}1 \\
2 \\
10 \\
5 \\
2 \\
\end{array}$ & $\begin{array}{c}5.0 \\
10.0 \\
50.0 \\
25.0 \\
10.0\end{array}$ & $\begin{array}{l}19 \\
215 \\
331 \\
378 \\
120\end{array}$ & $\begin{array}{l}1.8 \\
20.2 \\
31.1 \\
35.7 \\
11.2\end{array}$ \\
\hline
\end{tabular}

Training in 


\begin{tabular}{lcccccccccccc}
\hline ME & & & & & & & & & & & & \\
Yes & 31 & 10.8 & 98 & 30.1 & 65 & 27.7 & 3 & 21.4 & 10 & 50.0 & 207 & 23.5 \\
No & 257 & 89.2 & 228 & 69.9 & 169 & 71.9 & 11 & 78.6 & 10 & 50.0 & 675 & 76.5 \\
\hline
\end{tabular}

Note: Responses lesser than 1,067 indicates missing data.

$M E=$ Multicultural Education.

Participants in this study were predominantly female (96.6\%). Similar patterns were evident across the different categories of preschools. The sample reflects the population distribution as teaching profession has always been predominantly a female profession in Malaysia, particularly at the early childhood level ('Cuepacs concerned about female dominance', 2010). In terms of racial distribution, most preschool providers were made up of teachers from multi-ethnic backgrounds, except for Religious-based and KEMAS preschools which are generally monocultural in nature. In terms of age distributions, most participants aged between 41-50 years old and they had no specific training on multicultural education as components of multicultural education are infused into the overall teacher education program. Only $23.5 \%$ of the preschool teachers had undergone specific trainings on multicultural education.

\section{Instrument}

A self-report questionnaire was employed to collect the necessary data for this study. Two psychometric instruments underpin this questionnaire; The Teachers' Training Multicultural Education Scale (TTMES) and Multicultural Teaching Scale (MTS). The item-total statistics and overall Cronbach's alpha values for both instruments are presented in Table 2.

Table 2 Item-Total Statistics for TTMES and MTS

\begin{tabular}{|c|c|c|c|c|c|c|c|}
\hline \multicolumn{4}{|c|}{$\begin{array}{c}\text { Teachers' Training Multicultural Education Scale } \\
\text { (TTMES) (10 item) }\end{array}$} & \multicolumn{4}{|c|}{ Multicultural Teaching Scale (MTS) } \\
\hline \multicolumn{4}{|c|}{ Measuring Preschool Teachers Perceived Training } & \multicolumn{4}{|c|}{ Measuring Preschool Teachers' Attitudes } \\
\hline & $\begin{array}{c}\text { Corrected } \\
\text { Item-Total } \\
\text { Correlation }\end{array}$ & $\begin{array}{c}\text { Squared } \\
\text { Multiple } \\
\text { Correlation }\end{array}$ & $\begin{array}{l}\text { Cronbach's Alpha if } \\
\text { Item Deleted }\end{array}$ & & $\begin{array}{c}\text { Corrected } \\
\text { Item-Total } \\
\text { Correlation }\end{array}$ & $\begin{array}{c}\text { Squared } \\
\text { Multiple } \\
\text { Correlation }\end{array}$ & $\begin{array}{l}\text { Cronbach's } \\
\text { Alpha if Item } \\
\text { Deleted }\end{array}$ \\
\hline $\mathrm{T} 1$ & .76 & .67 & .92 & A1 & .43 & .54 & .69 \\
\hline $\mathrm{T} 2$ & .75 & .68 & .92 & A2 & .42 & .57 & .69 \\
\hline $\mathrm{T} 3$. & .79 & .70 & .92 & A3 & .43 & .36 & .69 \\
\hline $\mathrm{T} 4$ & .79 & .68 & .92 & A4 & .32 & .46 & .71 \\
\hline $\mathrm{T} 5$ & .73 & .66 & .92 & A5 & .42 & .37 & .69 \\
\hline T6 & .79 & .66 & .92 & A6 & .38 & .43 & .70 \\
\hline $\mathrm{T} 7$ & .78 & .69 & .92 & A7 & .40 & .49 & .69 \\
\hline $\mathrm{T} 8$ & .70 & .54 & .92 & A8 & .48 & .51 & .68 \\
\hline T9 & .70 & .57 & .92 & A9 & .28 & .20 & .71 \\
\hline $\mathrm{T} 10$ & .50 & .39 & .93 & - & - & - & - \\
\hline \multicolumn{4}{|c|}{ Overall Cronbach's Alpha $(\alpha)=0.93$} & \multicolumn{4}{|c|}{ Overall Cronbach's Alpha $(\alpha)=0.72$} \\
\hline
\end{tabular}


The TTMES is made up of 10 items that measure any formal training that the preschool teachers have received whether it is directly or indirectly related to multicultural education. The instrument is a unidimentional, four point likert scale, with possible responses range from 'strongly disagree' to 'strongly agree'. The items were first constructed in English language based on Zeichner (1993)'s framework on 'Elements to Educate Teacher for Diversity' and relevant literatures (e.g., Baldwin, Buchanan \& Rudisill, 2007). It was later translated into Malay language, content validated by a panel of experts from the fields of early childhood education, educational psychology and sociology of education. Both English and Malay Language items were presented in the questionnaire. Reliability test revealed that the TTMES has a Cronbach's alpha value $(\alpha)$ of 0.93 . Preschool teachers' attitudes towards multicultural education, on the other hand, were gauged by the Multicultural Teaching Scale (MTS), developed by Wayson (1993). The validity and reliability of this scale was supported by literatures (e.g., Gorham, 2001). Nevertheless, in order to be applied in the local preschool context, items in MTS were screened and adapted. The same procedures as TTMES were used to translate the instrument into Malay Language and its content validity was established by a panel of experts. The adapted instrument originally has 10 items $(\alpha=.60)$. However, item-10 was dropped to increase the scale's reliability to 0.72 .

\section{Data Collection}

The questionnaires were sent to the participants at their respective preschools using either conventional post or given to their gate-keepers in the relevant ministries. In this study, the primary role of the gate-keepers was to disseminate questionnaires in a manner that could reach out to as many of the preschool teachers as possible. The questionnaires were completed anonymously by the participants and sent back to the researchers or the respective gate-keeper. As such, the confidentiality of the participants was preserved. This measure could also minimize the likelihood of social desirability bias as there were no face-to-face interaction with the researchers and the participants' identity was not revealed. The potential limitation concerning self-report responses is acknowledged in this study as there were still possibilities that altruistic and socially desirable response might be given by the respondents.

\section{Data Analysis}

Descriptive statistics (mean, standard deviation, percentages, frequency) were used to analyse teachers' training and attitudes towards multicultural education. Differences between the categories of preschool was analysed with a nonparametric test, the Kruskal-Wallis test, due to unequal sample size between the preschools. The minimum cell frequency to run Kruskal Wallis test is 5 or greater (Pallant, 2001). This underlying assumption was fulfilled in this study as the minimum cell frequency was 14 . The significant level for statistical analysis was set at alpha 0.05 and the data was analysed with Statistical Package for Social Sciences version 23 . The scores for negative items were reversed prior to data analysis.

\section{FINDINGS AND DISCUSSIONS}

\section{Preschool Teachers' Training on Multicultural Education}

Preschool teachers' trainings on multicultural education is showed in Table 3. All the items have recorded a total agreement (agree and strongly agree) of more than 90\%. The results 
indicate that the preschool teachers were highly positive about the trainings that they had received on multicultural education.

Table 3: The Training of Preschool Teachers

\begin{tabular}{|c|c|c|c|c|c|c|c|c|}
\hline \multirow[t]{2}{*}{ No } & \multirow[t]{2}{*}{ Items } & \multirow[t]{2}{*}{$\mathbf{M}$} & \multirow[t]{2}{*}{ S.D. } & \multicolumn{4}{|c|}{$\begin{array}{c}\text { Response Value Frequencies } \\
\text { f }(\%)\end{array}$} & \multirow{2}{*}{$\begin{array}{c}\text { Total } \\
\text { \% of } \\
\text { Agreement } \\
\end{array}$} \\
\hline & & & & SDA & DA & A & SA & \\
\hline $\mathrm{T} 1$ & $\begin{array}{l}\text { The training I have received has } \\
\text { helped me to develop a clear } \\
\text { understanding of multicultural } \\
\text { education. }\end{array}$ & 3.03 & 0.51 & $\begin{array}{c}16 \\
(1.6)\end{array}$ & $\begin{array}{c}66 \\
(6.7)\end{array}$ & $\begin{array}{c}773 \\
(78.3)\end{array}$ & $\begin{array}{c}132 \\
(13.4)\end{array}$ & 91.7 \\
\hline $\mathrm{T} 2$ & $\begin{array}{l}\text { The training I have received has made } \\
\text { me realized the impact of prejudice } \\
\text { and racism on children. }\end{array}$ & 3.06 & 0.54 & $\begin{array}{c}17 \\
(1.7)\end{array}$ & $\begin{array}{c}71 \\
(7.2)\end{array}$ & $\begin{array}{c}735 \\
(74.8)\end{array}$ & $\begin{array}{c}160 \\
(16.3)\end{array}$ & 91.1 \\
\hline T3 & $\begin{array}{l}\text { The training I have received has } \\
\text { taught me how to guide preschool } \\
\text { children to examine their prejudices } \\
\text { towards other ethnic groups. }\end{array}$ & 3.06 & 0.55 & $\begin{array}{c}19 \\
(1.9)\end{array}$ & $\begin{array}{c}65 \\
(6.6)\end{array}$ & $\begin{array}{c}742 \\
(75.3)\end{array}$ & $\begin{array}{c}160 \\
(16.2)\end{array}$ & 91.5 \\
\hline $\mathrm{T} 4$ & $\begin{array}{l}\text { The training I have received has } \\
\text { enabled me to apply specific } \\
\text { technique(s) to handle prejudices } \\
\text { among children. }\end{array}$ & 3.03 & 0.50 & $\begin{array}{c}14 \\
(1.4)\end{array}$ & $\begin{array}{c}69 \\
(7.0)\end{array}$ & $\begin{array}{c}774 \\
(78.7)\end{array}$ & $\begin{array}{c}127 \\
(12.9)\end{array}$ & 91.6 \\
\hline T5 & $\begin{array}{l}\text { The training I have received has made } \\
\text { me realized the important roles } \\
\text { played by teachers in multicultural } \\
\text { education. }\end{array}$ & 3.22 & 0.55 & $\begin{array}{c}12 \\
(112)\end{array}$ & $\begin{array}{c}34 \\
(3.5)\end{array}$ & $\begin{array}{c}666 \\
(67.7)\end{array}$ & $\begin{array}{c}272 \\
(27.6)\end{array}$ & 95.3 \\
\hline T6 & $\begin{array}{l}\text { The training I have received has } \\
\text { taught me how to identify cultural } \\
\text { bias elements in the teaching } \\
\text { materials. }\end{array}$ & 3.03 & 0.52 & $\begin{array}{c}16 \\
(1.6)\end{array}$ & $\begin{array}{c}71 \\
(7.3)\end{array}$ & $\begin{array}{c}757 \\
(77.8)\end{array}$ & $\begin{array}{c}129 \\
(13.3)\end{array}$ & 91.1 \\
\hline $\mathrm{T} 7$ & $\begin{array}{l}\text { The training I have received has } \\
\text { enabled me to develop learning } \\
\text { materials that are appropriate for } \\
\text { children with diverse cultural } \\
\text { backgrounds. }\end{array}$ & 3.13 & 0.53 & $\begin{array}{c}11 \\
(1.1)\end{array}$ & $\begin{array}{c}54 \\
(5.5)\end{array}$ & $\begin{array}{c}714 \\
(72.9)\end{array}$ & $\begin{array}{c}201 \\
(20.5)\end{array}$ & 93.4 \\
\hline T8 & $\begin{array}{l}\text { The training I have received has } \\
\text { introduced me to various cultural } \\
\text { characteristics in Malaysia. }\end{array}$ & 3.16 & 0.55 & $\begin{array}{c}10 \\
(1.0)\end{array}$ & $\begin{array}{c}51 \\
(5.2)\end{array}$ & $\begin{array}{c}685 \\
(70.1)\end{array}$ & $\begin{array}{c}231 \\
(23.6)\end{array}$ & 93.7 \\
\hline T9 & $\begin{array}{l}\text { The training I have received has } \\
\text { provided me adequate knowledge on } \\
\text { intercultural influences (e.g., food, } \\
\text { clothing, language etc.) among the } \\
\text { different ethnic groups in Malaysia. }\end{array}$ & 3.13 & 0.54 & $\begin{array}{c}8 \\
(0.8)\end{array}$ & $\begin{array}{c}66 \\
(6.7)\end{array}$ & $\begin{array}{c}704 \\
(71.5)\end{array}$ & $\begin{array}{c}207 \\
(21.0)\end{array}$ & 92.5 \\
\hline
\end{tabular}

Note: M=mean; S.D. = Standard Deviation

Generally, preschool teachers felt that the trainings helped them to develop awareness and understanding towards multicultural education. The teachers felt that they have been provided with adequate knowledge and skills to teach and manage preschool children from diverse cultural backgrounds. Item $\mathrm{T} 5$ 'The training I have received has made me realized the important roles played by teachers in multicultural education' has recorded the highest percentage of total agreement, 95.3\% (agree $=67.7 \%$; strongly agree $27.6 \%$ ). The result 
suggests that teacher education have instilled awareness amongst the preschool teacehrs about the important roles that they played in multicultural education. Two items with the least percengates of total agreement were $\mathrm{T} 2$ 'The training I have received has made me realized the impact of prejudice and racism on children' $(91.1 \%$, agree $=74.8 \%$; strongly agree $=16.3 \%$ ) and $\mathrm{T} 6$ 'The training I have received has taught me how to identify cultural bias elements in the teaching materials' $(91.1 \%$, agree $=77.8 \%$; strongly agree $=13.3 \%)$. The findings suggest that the converage of teacher training program on specific topics like prejudicism and racism as well as management of biases in teaching materials are less direct and comphrehensive compare to other aspect of multicultural education.

\section{Preschool Teachers' Attitudes towards Multicultural Education}

Table 4 reveals the preschool teachers' attitudes towards multicultural education. The overall findings suggest that preschool teachers have conflicting attitudes. At one point, they have extremely positive attitudes towards multicultural education, as shown by responses in Items A1, A2, A4, A6, and A9.

Table 4: Teachers' Attitudes towards Multicultural Education

\begin{tabular}{|c|c|c|c|c|c|c|c|c|}
\hline \multirow[t]{2}{*}{ No } & \multirow[t]{2}{*}{ Items } & \multirow[t]{2}{*}{ Mean } & \multirow[t]{2}{*}{ S. D. } & \multicolumn{4}{|c|}{$\begin{array}{c}\text { Response Value Frequencies } \\
\text { f }(\%)\end{array}$} & \multirow{2}{*}{$\begin{array}{c}\text { Total } \\
\text { \% of } \\
\text { Agreement } \\
\end{array}$} \\
\hline & & & & SDA & DA & $\mathbf{A}$ & SA & \\
\hline $\mathrm{A} 1$ & $\begin{array}{l}\text { I find the idea of teaching } \\
\text { culturally diverse preschool } \\
\text { children rewarding. }\end{array}$ & 3.00 & 0.53 & $\begin{array}{c}12 \\
(1.2)\end{array}$ & $\begin{array}{c}111 \\
(10.7)\end{array}$ & $\begin{array}{c}780 \\
(75.1)\end{array}$ & $\begin{array}{c}135 \\
(13.0)\end{array}$ & 88.1 \\
\hline $\mathrm{A} 2$ & $\begin{array}{l}\text { I can learn a great deal from } \\
\text { preschool children with } \\
\text { culturally different } \\
\text { backgrounds. }\end{array}$ & 3.13 & 0.51 & $\begin{array}{c}9 \\
(0.9)\end{array}$ & $\begin{array}{c}52 \\
(5.0)\end{array}$ & $\begin{array}{c}770 \\
(74.0)\end{array}$ & $\begin{array}{c}210 \\
(20.2)\end{array}$ & 94.2 \\
\hline A3 & $\begin{array}{l}\text { I feel that multicultural training } \\
\text { for preschool teachers is not } \\
\text { necessary. }\end{array}$ & 2.99 & 0.68 & $\begin{array}{c}26 \\
(2.5)\end{array}$ & $\begin{array}{c}171 \\
(16.5)\end{array}$ & $\begin{array}{c}623 \\
(60.1)\end{array}$ & $\begin{array}{c}217 \\
(20.9)\end{array}$ & 81.0 \\
\hline A4 & $\begin{array}{l}\text { Preschool teachers have to be } \\
\text { aware of their preschool } \\
\text { children's cultural } \\
\text { backgrounds. }\end{array}$ & 3.25 & 0.49 & $\begin{array}{c}4 \\
(0.4)\end{array}$ & $\begin{array}{l}18 \\
(1.7)\end{array}$ & $\begin{array}{c}734 \\
(70.6)\end{array}$ & $\begin{array}{c}283 \\
(27.2)\end{array}$ & 97.8 \\
\hline A5 & $\begin{array}{l}\text { It is not the preschool teacher's } \\
\text { responsibilities to encourage } \\
\text { pride in one's culture. }\end{array}$ & 2.97 & 0.70 & $\begin{array}{c}23 \\
(2.2)\end{array}$ & $\begin{array}{c}198 \\
(19.1)\end{array}$ & $\begin{array}{c}601 \\
(58.1)\end{array}$ & $\begin{array}{c}211 \\
(20.4)\end{array}$ & 78.5 \\
\hline A6 & $\begin{array}{l}\text { Regardless of the ethnic } \\
\text { composition in a classroom, it } \\
\text { is important for all preschool } \\
\text { children to be aware of } \\
\text { multicultural diversity. }\end{array}$ & 3.08 & 0.4 & $\begin{array}{c}8 \\
(0.8)\end{array}$ & $\begin{array}{c}47 \\
(4.5)\end{array}$ & $\begin{array}{c}832 \\
(80.2)\end{array}$ & $\begin{array}{c}151 \\
(14.5)\end{array}$ & 94.7 \\
\hline A7 & $\begin{array}{l}\text { Multicultural education is not } \\
\text { relevant for preschool children. }\end{array}$ & 3.00 & 0.63 & $\begin{array}{c}21 \\
(2.0)\end{array}$ & $\begin{array}{c}145 \\
(14.1)\end{array}$ & $\begin{array}{c}672 \\
(65.4)\end{array}$ & $\begin{array}{c}189 \\
(18.4)\end{array}$ & 83.8 \\
\hline A8 & $\begin{array}{l}\text { Teaching preschool children } \\
\text { about cultural diversity will } \\
\text { only create social conflict in the } \\
\text { classroom. }\end{array}$ & 3.03 & 0.64 & $\begin{array}{c}20 \\
(1.9)\end{array}$ & $\begin{array}{c}138 \\
(13.3)\end{array}$ & $\begin{array}{c}668 \\
(64.5)\end{array}$ & $\begin{array}{c}210 \\
(20.3)\end{array}$ & 84.8 \\
\hline
\end{tabular}




\begin{tabular}{llccccc}
\hline A9 $\quad \begin{array}{l}\text { I believe that teaching methods } \\
\text { need to be adapted when } \\
\text { teaching preschool children } \\
\text { with diverse cultural } \\
\text { backgrounds. }\end{array}$ & & 17 & 187 & 718 & 115 & 80.3 \\
& & & $(1.6)$ & $(18.0)$ & $(69.2)$ & $(11.1)$ \\
Note: & M $=$ mean; S.D. $=$ Standard Deviation
\end{tabular}

On the other hand, the teachers' high percentage of agreement on Items A3, A5, A7 and A8 suggest misconception and misunderstandings about the fundamental principles of multicultural education training and practices. As a matter of fact, more than two thirds of the respondents agreed that multicultural training for preschool teachers are unnecessary, it is irrelevant for preschool children and the teaching of cultural diversity will only create social conflicts in the classroom and they do not have the responsibilities to encourage pride in one's culture.

\section{Differences in Training and Attitudes by Categories of Preschools}

To compare preschool teachers' training and attitudes towards multicultural education according to the different categories of preschools, the Kruskal-Wallis test, a nonparametric test was carried out. This analysis was run due to unequal sample size between the five categories of preschool schools. The Private (584.56) and PERPADUAN (500.81) preschools teachers were most positive about their trainings while the Religious-based JAIN (379.57) preschool teachers were least positive. Significant difference were found between the five categories of preschools $[\mathrm{H}(4)=26.680$, Asymp. Sig., $p<0.05]$ (Table 5).

Table 5 Comparison of Teachers' Training and Attitudes by Categories of Preschools

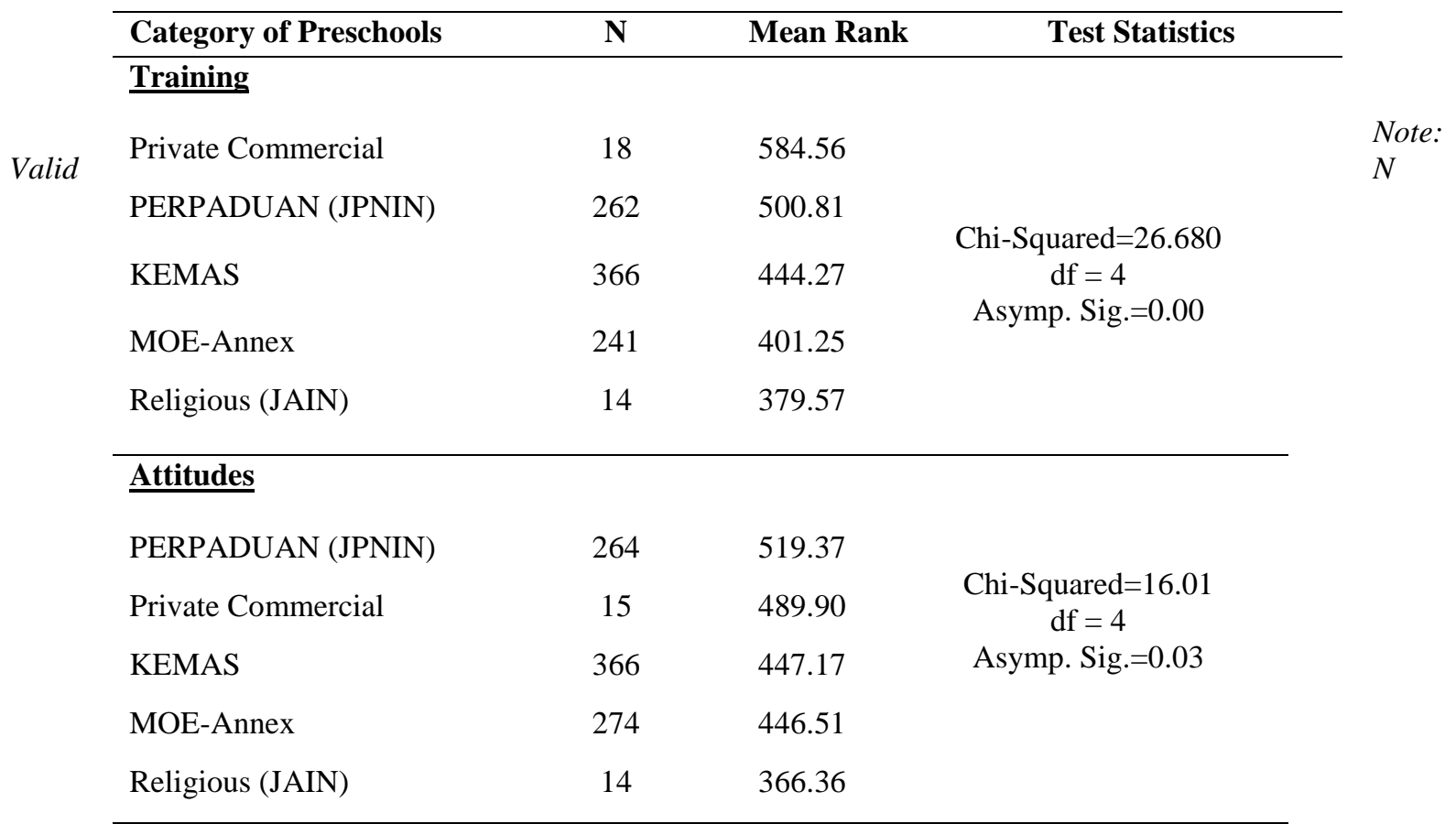

(Listwise). Missing data were not included in the analysis. The minimum expected cell frequency for Kruskal Wallis Test is 5 or greater (Pallant, 2001). 
Table 5 shows that the PERPADUAN (519.37) preschool teachers have the most positive attitudes while teachers from the Religious-based JAIN (366.36) preschools have the least positive attitudes. Significant differences were found across the different categories of preschools $[\mathrm{H}(4)=16.01, p<0.05]($ Table 5$)($ Figure 1$)$.

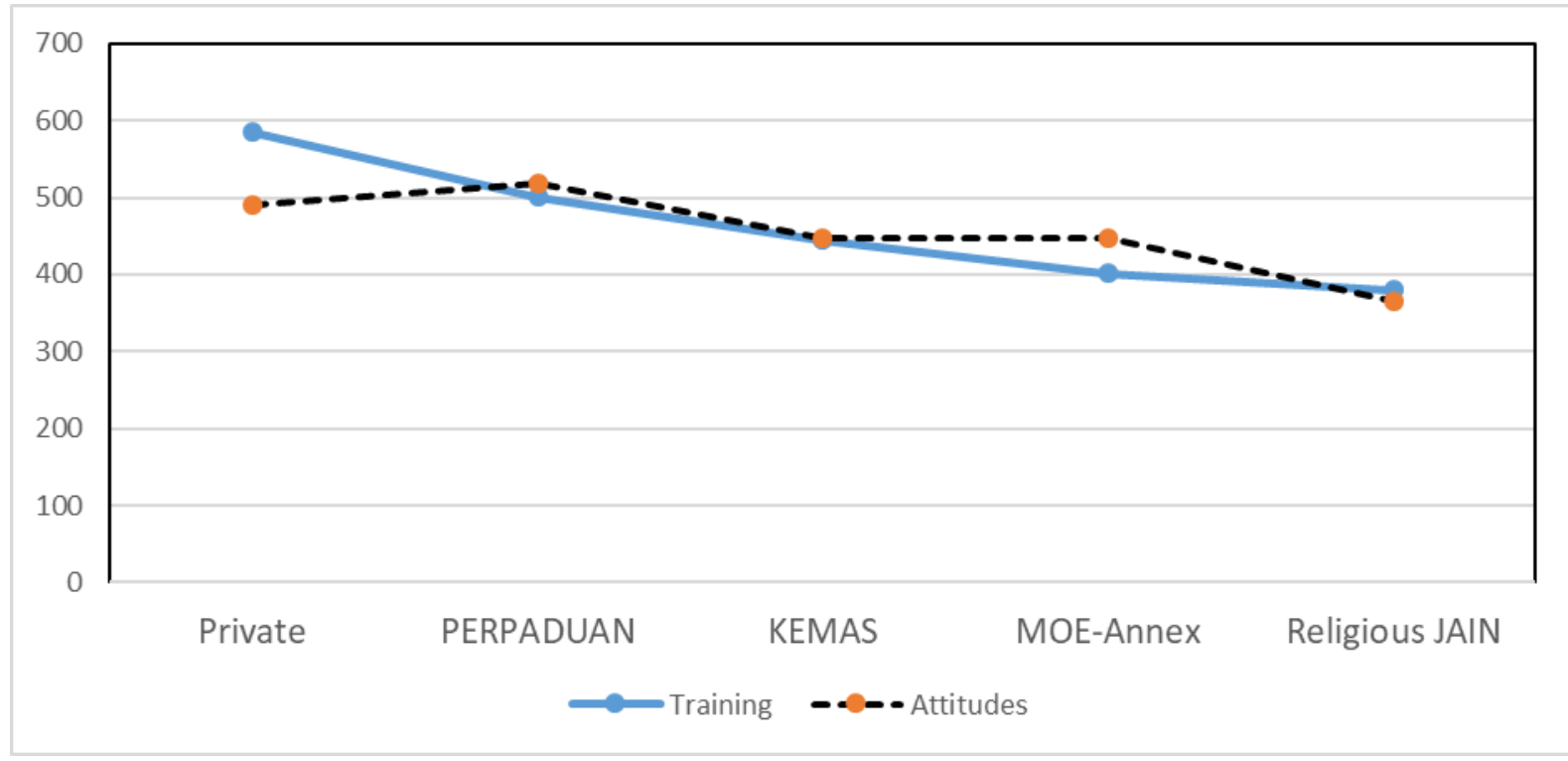

Figure 1: Mean ranks on teachers' training and attitudes towards multicultural education by categories of preschools.

\section{IMPLICATIONS}

In general, Malaysian preschool teachers have rated their professional trainings positively. They believed that teacher education has instilled them with awareness and understanding about multicultural education. However, the extent to which teachers actually understood the concept of multiculturalism was doubtful in view that two thirds of the teachers demonstrated misconception about the fundamental principles of multicultural education when their attitudes towards multicultural education were examined. For instance, most of the preschool teachers perceived multicultural training as unnecessary; they believe that it is not their responsibilities to encourage pride in one's culture. Some teachers even see multicultural education as irrelevant for the teaching of cultural diversity will only create social conflicts in the classroom. Such findings reflect a lack of true understandings in multicultural education (Phoon, Abdullah \& Abdullah, 2012; Lee \& Dallman, 2008). In fact, teachers lacking in multicultural trainings are more reluctant to talk about ethnicity in class (Bolgatz, 2005). This is in line with Lee and Dallman's (2008) findings that teachers generally fail to consider the hidden assumptions of cultural diversity and misconception is likely to occur.

There are obvious shortcomings in the current teacher training program since more than $75 \%$ of the preschool teachers $(n=678)$ indicated that they did not undergo any specific trainings on multicultural education. The education programs should be reviewed to provide 
more inclusive and impactful training on multiculturalism, to go beyond a 'tourist' approach. Critical issues like managing stereotyping, biases and discriminatory behaviour among young children need to be addressed in the curricular. It should not be assumed that teachers from a multi-ethnic country like Malaysia naturally have understanding about multiculturalism. In fact, the component of multiculturalism should be more extensive, based on sound research and driven by evidence of what works in the local context (Zeichner, 1993; Gorham, 2001). This study also discovered that attitudes towards multicultural education differed according to categories of preschools. Teachers from preschools with culturally diverse settings (e.g., PERPADUAN and private preschools) seem to have more favourable attitudes towards multicultural education. Future studies may examine how teachers these mono-cultural schools develop positive attitudes towards multicultural education. The PERPADUAN or unity preschools, for instance, were set up by the Department of National Unity and Integration, with the objective of nurturing unity values at an early stage so that children will love their country and adapt themselves to live harmoniously in a multi-racial community. Past studies showed that positive attitudes come with positive experiences which can be developed through interactions with individuals from culturally diverse backgrounds (Lea, 2004). Teachers from the PERPADUAN preschools could have been exposed to richer intercultural experiences which shaped their positive attitudes and beliefs about multicultural education (Phoon, Abdullah \& Abdullah, 2012). Teachers from the mono-cultural preschools (e.g., KEMAS and Religious-based preschools), on the other hand, seem to have more negative attitudes towards multicultural education. It is likely that teachers from monocultural preschools did not see the need to address cultural diversity issues in teaching since their immediate school context is made up of $100 \%$ Malay and Muslim students. These teachers may consider other priorities as more important, and felt that dealing with an issue such as cultural diversity would be artificial when it was not a major concern for either the school or its community. In addition, the attitudes of the teachers can also be reinforced by their sociocultural experiences as the teaching workforce in such schools is usually monocultural in nature. It is important for all preschool teachers to realize that multi-cultural education should be implemented even in mono-cultural classroom. To alter the teachers' attitudes and beliefs about multi-cultural education, in-service courses can be offered. Effective training will provide the necessary exposure and experiences to change the teachers' attitudes and enhance their readiness to carry out multicultural teaching (Gorski, 2009).

\section{CONCLUSION}

Early Childhood education is essential in promoting cross-cultural understanding, recognition, and celebration of diversity at an early age. For this reason, preschool teachers play key roles in successful implementation of multicultural education and laying the foundation for cultural acceptance and positive racial interaction during early childhood. This study examined Malaysian preschool teachers' training and attitudes towards multicultural education through a large scale survey research, which involved more than one thousand preschool teachers from 267 private and government preschools in the country. Findings from this study highlights the gaps in existing teacher training program in Malaysia. Future studies may fill in the literature gaps by developing a national framework for Multicultural Teacher Education in Malaysia to provide guidelines for all the Teacher Training Colleges, 
universities and preschool providers in the country. The framework should cover all key elements on diversity, ideology, knowledge, teacher learning, teacher instructional practices and outcomes (Cochran-Smith, 2003; Zeichner, 1993). Without a national framework for Multicultural Teacher Education, it is difficult to effectively train preschool teachers to work in both mono- and multi-cultural settings. Effective training will not only help preschool teachers to develop a clearer sense of own cultural identities, address the nature and causes of prejudices and racism but also encourage them to self-reflect and avoid any predetermined biases when planning and conducting lessons. In addition, the histories, cultural values and contribution of various ethno-cultural groups need to be included in teacher education program (Zeichner, 1993). This is to ensure that preschool teachers are equipped with adequate content knowledge, pedagogical skills and readiness to embraces diversity (Gorham, 2001; Glazier, Charpentier \& Boone, 2011). In conclusion, if the goal of teacher education is to prepare teachers who can deliver instructions to all learners and settings, then the professional development of teachers must be intimately connected to multicultural education.

\section{ACKNOWLEDGEMENTS}

This study was funded by the Universiti Sains Malaysia (USM), Research University Grant (1001/PGURU/811096). The contributions of experts in validating the research instruments were much appreciated. Special thanks also go to the research team members who have contributed in this research project.

\section{REFERENCES}

Abdullah, A. C. (2009). Multicultural education in early childhood: Issues and challenges. Journal of International Cooperation in Education, 12(1), 159-175.

Abdullah, A.C., Mohd Yusof, N. \& Ahmad, N. (2010). Beliefs, Attitudes and Concepts Held by Preschool Teachers Pertaining to Multicultural Education. Proceedings of the $3^{\text {rd }}$ International Conference of Education, Research and Innovation, Madrid, 15-17 November 2010, pp. 243-253.

Abdullah, A. C., Najeemah Mohd Yusuf \& Norlida Ahmad. (2010). Beliefs and attitudes held by preschool teacehrs pertaining to multicultural education. Proceeding in International Conference of Education, Research and Innovation, 243-253.

Abdullah, A. C., Nor Hashimah Hashim, Tang, K. W., Abdullah, M. N. L. Y., Najeemah Mohd Yusuf, \& Norlida Ahmad. (2011).

Construction of a Model for Multicultural Education in Early Childhood through Investigating the State-ofPractice in Malaysia. Research University Grant, Universiti Sains Malaysia.

Assaf, L. C., Garza, R., \& Battle, J. (2010). Multicultural teacher education: Examining the perception, practices and coherence in one teacher preparation program. Teacher Education Quarterly, 37(2), 115-135.

Banks, J. A., Cookson, P., Gay, G., Hawley, W. D., Irvine, J. J., Nieto, S., Schofield, J. W., \& Stephan, W. G. (2001). Diversity within unity: Essential principles for teaching and learning in multicultural society. Seattle: Centre for Multicultural Education, University of Washington.

Baldwin, S. C., Buchanan, A. M., \& Rudisill, M. E. (2007). What teacher candidates learned about diversity, social justice, and themselves from service-learning experiences. Journal of Teacher Education, 54(4), 31527.

Brahim, T. K., \& Syarif, S. M. (2010). Why multicultural education is need for the early childhood education in developing a new society. National Teacher Education Journal, 3(2), 139-152.

Bolgatz, J. (2005). Revolutionary talk: Elementary teacher and students discuss race in a social studies class. Social Studies, 96(6), 259-264.

'Cuepacs concerned about female dominance', The Star Online, 22 February 2010. 
Curriculum Development Center. (2008). Early childhood care and education policy implementation review. Kuala Lumpur: Curriculum Development Center, Ministry of Education Malaysia.

Cochran-Smith, M. (2003). Standing at the crossroads: Multicultural teacher education at the beginning of the $21^{\text {st }}$ Century. Multicultural Perspectives, 5(3), 3-11.

Denham, S. A., Bassett, H., Mincic, M., Kalb, S., Way, E., Wyatt, T., \& Segal, Y. (2012). Social-emotional learning profiles of preschoolers' early school success: A person-centered approach. Learning and individual Differences, 22(2), 178-189.

European Commission. (2010). How can teacher education and training policies prepare teachers to teach effectively in culturally diverse setting? Retrieved 15 March 2016 from http://www.atee1.org/uploads/EUpolicies/pla_teaching_in_culturally_divers_settings.pdf

Glazier, J., Charpentier , A., \& Boone, H. (2011). A Transformational Journey: A Framework for Pre-Service Teachers to Learn about Diversity through Service Learning. Journal for Civic Commitment, 17, 1-15.

Gorham, E. (2001). Multicultural teaching competence as perceived by elementary school teachers. Unpublished doctoral thesis, Virginia Polytechnic Institute and State University, Blacksburg, VA.

Gorski, P. C. (2009). What we're teaching teachers: An analysis of multicultural teacher education coursework syllabi. Teaching and Teacher Education, 25, 309-318.

'Lea, V. (2004). The reflective cultural portfolio: Identifying public cultural scripts in the private voices of white student teacher. Journal of Teacher Education, 55(2), 117-127.

Lee, S., \& Dallman, M.E. (2008). Engaging in a reflective examination about diversity: Interviews with three preservice teachers. Mulitcultural Education, 15(4), 36 - 45.

Ogletree, Q., \& Patricia, L. (2010). Implementing multicultural practices in early childhood education. National Forum of Multicultural Issues Journal, 9(1), 1-9.

Pallant, J. (2001). SPSS Survival Manual: A Step Guide to Data Analysis using Windows (version 10). NSW: Allen and Unwin.

Phoon, H. S., Abdullah, M. N. L. Y, \& Abdullah, A. C. (2012). Unveiling Malaysian Preschool Teachers' Perceptions and Attitudes in Multicultural Early Childhood Education. Asia-Pacific Education Researcher Journal, 22(4), 427-438.

Sharifah, N., \& Mohamed, N. A. (2011). Multicultural education in Malaysia perspective: instruction and assessment. International Association for Educational Assessment Conference, 23-28 November 2011, Manila Philippines.

Wayson, W. W. (1993). Multicultural Teaching Scale. Plain, Ohio: Synergetic Development.

Zeichner, K. M. (1993). Connecting genuine teacher development to the struggle for social justice. Journal of Education for Teaching, 19(1), 5-20. 